\title{
Selected Reference Books of 1955-1956
}

\section{INTRODUCTION}

$\mathrm{L}$ IKE THE preceding articles in this semiannual series ${ }^{1}$ this survey is based on notes written by members of the staff of the Columbia University Libraries. Notes written by assistants are signed with initials. ${ }^{2}$

As the purpose of the list is to present a selection of recent scholarly and foreign works of interest to reference workers in university libraries, it does not pretend to be either well-balanced or comprehensive. Code numbers (such as All and 1A26) have been used to refer to titles in the Guide ${ }^{3}$ and its first Supplement.

\section{BIBLIOGRAPHY}

Leipzig. Deutsche Bücherei. Bibliographie der versteckten Bibliographien aus deutschsprachigen Büchern und Zeitschriften der Jahre 1930-1953. Leipzig, Verlag für Buch-und Bibliothekswesen [1956] 371p. (Sonderbibliographien der deutschen Bücherei 3) DM 50.

Covering the years 1930-53, this valuable contribution lists German bibliographies published as parts of books or in periodicals. Although it aims to be comprehensive, only bibliographies of some substance, generally consisting of more than 60 titles, are included. Arrangement is alphabetical by subject with a classified index of subject headings. The editors intend to keep it up to date by an annual publication, Jahresverzeichnis der Bibliographien des deutschen

${ }^{1} C R L$, January and July issues, starting January, 1952 .

${ }^{2}$ Eleanor Buist, Eileen Grady, Kenneth Lohf, Suzanne Szasz, Eugene Sheehy, John Neal Waddell.

a Constance M. Winchell, Guide to Reference Books (7th ed.; Chicago, ALA, 1951); Supplement (Chicago: ALA, 1954).

Miss Winchell is reference librarian, Columbia University.
Schriftums, which will list separately published bibliographies as well.-S.S.

U.S. Library of Congress. British Manuscripts Project; a Checklist of the Mi. crofilms Prepared in England and Wales for the American Council of Learned Societies, 1941-1945, comp. by Lester K. Born. Washington, D.C., Photoduplication Service, Library of Congress, 1955. 179p. \$2.

During the war some five million pages of manuscript, and a few rare books, in British public and private collections were filmed, and the films subsequently turned over to the Library of Congress. The present check list is compiled to indicate to the American scholar something of the contents of the collection and to serve, as well, as a source for ordering copies of the films. Arrangement is first by location, then by name of collection and manuscript number, with a brief descriptive listing for each item. Although the index is restricted to personal and geographic names, it includes more than 10,000 entries, with subjects, editors, translators, etc., as well as authors.-J.N.W.

\section{Periodicals}

Handbuch der deutschsprachigen Presse ausserhalb Deutschlands. Würzburg, Holzner, 1956-

A geographically arranged list of current German language newspapers and periodicals published outside Germany and concerned primarily with trade and manufacturing, although publications dealing with politics, humanities, economics and political science are also listed. Included for each title is the following information: address, editor, publisher, date of founding, frequency of publication, amount of circulation, format, pagination, type of content, audience intended for, and advertising policies. There is a title index. Further editions are planned.-K.L.

Nifor: Guide to Indian Periodicals, 
1955/1956- . Poona, India, National Information Service, 1955-

The first directory of its kind in India, this guide gives a classified listing of 2,127 Indian periodicals and newspapers, and a separate alphabetical list of 1,526 additional unclassified titles. The classified section is in four main sequences: language, subject, periodicity and geographical, and is followed by 12 statistical tables. The language section gives the main information about each periodical including title, date of establishment, size, frequency, cost, editors and publishers, with references to subject classifications.

\section{DisSERTATIONS}

Microfilm Abstracts Author Index, covering volumes 1-11, 1938-1951 of Microfilm Abstracts (now Dissertation Abstracts), comp. by the Georgia Chapter, Special Libraries Association, with the cooperation of University Microfilms. Atlanta, Georgia Chapter, Special Libraries Association, 1956. 27p. \$2.

A useful index compiled to make more readily available the material in the first eleven volumes of Microfilm Abstracts. Author's names are in a straight alphabetical arrangement with reference to volume, number and page.

\section{LIBRARIES}

Wieckowska, Helena and Pliszczynska, Hanna. Podreczny slownik bibliotekarza. Warszawa, Panstwowe Wydawnictwo Naukowe, 1955. 309p. zl 61.80.

This dictionary of Polish library terms includes about 3000 words used in the profession and in allied fields. Definitions are in Polish, with Polish synonyms for each word and equivalents in English, French, German, and Russian. There are separate glossaries for each of these languages giving for each foreign term its Polish equivalent.-S.S.

\section{Psychology}

Grinstein, Alexander. The Index of Psychoanalytic Writings. New York, International Universities Press, 1956- . v.l- . \$75 the set.
Contents: v.l Aall-Freud.

A revision and considerable expansion of John Rickman's Index psychoanalyticus, this valuable and comprehensive index includes books, monographs, periodical articles, reviews and abstracts written by psychoanalysts or concerning the subject of psychoanalysis, and published in any language from 1900 through 1952. The main listing is by author, but there is to be a subject index in the concluding volume. A set of appendices lists the works of major writers chronologically; in the first volume this includes the writings of Karl Abraham, Sándor Ferenczi and Sigmund Freud. For greater usefulness each foreign title is followed by an English translation. To be completed in five volumes. - K.L.

\section{Social ScIENCES}

\section{America Votes: a Handbook of Contem-} porary American Election Statistics, comp. and ed. by Richard M. Scammon. N.Y., Macmillan, 1956- . v.1- . (Governmental Affairs Institute, 1- ) $\$ 12.50$.

A new handbook giving for each state "the vote and percentage figures of the most recent elections for President (1952), Governor, and the state's two sitting Senators, together with listings of the postwar vote for Congress." Each state section is preceded by an outline map showing counties, congressional districts, etc. 1952 statistics for President, Governors, etc. are broken down by county, and for cities of over 500,000 , maps and election statistics are given in the appropriate state section. Further details are enumerated in the Introduction.

The British Commonwealth, 1956. [1st ed.] London, Europa Publications, 1956. 918p. \$14.70.

An impressive compilation of general and statistical information on all countries and territories of the British Commonwealth. Three introductory essays " "The Evolution of the Commonwealth," "Downing Street," and "The Commonwealth: Economic Aspects") are followed by sections on the individual countries. The latter include articles (usually signed and by specialists) on geography, history and economic conditions, plus 
sections incorporating statistical tables and directory-type information on constitution, government, political parties, religion, press, finance, trade and industry, learned societies, museums, libraries and universities. A select bibliography, a directory of Commonwealth organizations, and a group of maps complete the volume. The index is only to regions, countries, territories, and islands, with a "synopsis of subjects" preceding the sections on individual areas. Future editions are planned.-E.S.

Naas, Bernard G. and Sakr, Carmelita S. American Labor Union Periodicals; a Guide to Their Location. Ithaca, N.Y., Cornell Univ., 1956. 175p. \$7.

Locates copies of files in 20 cooperating libraries. For each library indication is given of interlibrary loan and microfilming facilities. Pt.1, List of Union periodicals arranged alphabetically by name of union; pt.2, Regional union periodicals, arranged by state and city. Title indexes to each part.

\section{United Nations. Statistical Office. World Weights and Measures; Handbook for Statisticians. Provisional ed. New York, 1955. 225p. (Statistical Papers, Series M, No. 21.) \$2.}

A handbook compiled mainly for statisticians working in the field of international economics, which provides factors for converting magnitudes, quantities and values from the units in which they are stated to corresponding units in other systems. The material is divided into five sections: international systems and units of weight and measure; national systems and units of weight, measure and currency; unit weights of selected commodities; national currencies, with equivalents in U.S. currency; indexes of weights and measures, abbreviations and currencies. For magnitudes, equivalents are shown in the metric and British systems. For quantities, equal units in the single, usual system are shown (e.g., decimal equivalents of fractions, Gregorian equivalents of other calendar periods). For values, equivalents are given in U.S. dollars, and, where officially established, in grams of fine gold.-E.G.

Yearbook of the International Socialist Labour Movement, 1956/57- . Ed. by Julius Braunthal. London, Lincolns-Prager International Yearbook, 1956- . Annual. £3 3s.

Published "under the auspices of the Socialist international and the Asian socialist conference." Gives data on the socialist and labor parties of each country and on the international socialist organizations.

\section{DictionaRIES}

Chicago University. Oriental Institute. The Assyrian Dictionary. Chicago, Institute, 1956- . v.6- .

To be cited as the CAD (i.e., Chicago Assyrian Dictionary). v.6, H, (266p.) published first, to be continued by G, E, D, B, A, and thereafter to follow the sequence of the alphabet beginning with $I$ and $J$, each letter in a separate volume. An Assyrian-English dictionary giving meanings in English with examples and citations to literature.

Littré, Émile. Dictionnaire de la langue française. Édition integrale. Paris, Jean-Jacques Pauvert, 1956- . t.l- . $\$ 45$ a set.

T.1, A-Caz

Édition integrale; la seule complète des étymologies et des différents suppléments et additfs reclassés dans le texte selon les intentions de l'auteur.

A reprint of the famous Littré (Guide M173) in modern format in which the material in the Supplement of the early work has been incorporated into the main alphabet. Important for the history, etymology and grammar of the French language.

\section{Music}

Coffin, Berton. The Singer's Repertoire. New Brunswick, N.J., The Scarecrow Press, 1956. 839p. \$16.

A selective list of approximately 7,500 songs and arias, primarily those "sung by noteworthy or accepted singers," compiled as an aid to "all singers and teachers of singing in their repertoire problems." Under each of nine voice classifications (coloratura, lyric, dramatic and mezzo sopranos, contralto, lyric and dramatic tenors, baritone and bass) material is listed according to the various character- 
istics of songs-nationality, mood, technique, subject-and subdivided by language. Composer, title, range, and publisher are given in all cases. There is no index.-K.L.

\section{LITERATURE AND LANGUAGE}

Bibliografie ceské linguistiky za léta 1945-1950: jazykoveda obecná indoevnopská, slovanská a ceská. Zapracoval Zdenek Tyl. Praha, Nakladetelství ceskoslovenské Akademie Ved, 1955-

- (Ceskoslovenská Akademie Ved. Sekce jazyka a literatury. Studi a prameny.)

This is the first five-year volume in a new series of bibliographies on Czech linquistics. It succeeds an earlier series published annually from 1929-35 with the title, Bibliografie Ceskolovenskych praci linguistickych a filologickych. It is hoped to publish the new series quinquenially. This volume lists books and periodical articles, primarily in Czech but with some entries in other languages. Many entries are annotated and give references to reviews.

Cordié, Carlo. Avviamento allo studio della lingua e della letteratura francese. Milano, Marzorati, 1955. 1,222p. $\$ 10.75$.

Intended for Italian students as a companion to French studies, this guide is divided into three sections. Part One deals with general reference works and lists grammars, dictionaries, etc., needed for the study of the French language. Part Two, a bibliography of French literature from the earliest times to the present, is arranged by periods; under each, general works dealing with the literature of the period are followed by an alphabetical list of authors. The length of treatment of individual authors varies with the importance the compiler has attributed to each. Generally only standard editions of their collected works are listed and French and Italian articles predominate in the list of criticism. Part Three discusses histories of French literature and indexes Sainte-Beuve's articles. Although the presentation is in the form of bibliographical essays, a detailed index gives easy access to the work. There is a 200-page "Addenda e Corrigenda" which brings the work up to date.-S.S.
Critical Bibliography of French Literature: D. C. Cabeen, general ed. v.2, The Sixteenth century, ed. by Alexander H. Schutz. Syracuse, N.Y., Syracuse University Press, 1956. 365p. \$6.

For v.l see Guide R570; v.4, Supplement 1 R58.

This volume was compiled by a number of contributing specialists under the general editorship of D. C. Cabeen and follows the same general plan as the earlier volumes. Books, periodicals, articles and dissertations are listed, with annotations and, in many cases, references to reviews.

Miller, Edmund Morris. Australian Literature; a Bibliography to 1938 . Extended to 1950 , ed. with a historical outline and descriptive commentaries by Frederick T. Macartney. Sydney, Angus and Robertson, 1956. 503p. 84/.

Represents an extensive revision of Miller's two-volume Australian Literature (Guide R254) and extends the work to 1950 . The previous chronological grouping under literary form is abandoned in favor of a straight author listing, and the fiction, name and subject indexes dispensed with. The present work is limited to purely literary works, with translations, scholastic and critical works, and children's books largely excluded. There are biographical notes on most authors and brief descriptive annotations for many individual works. References to critical studies are, for the most part, no longer included.-E.S.

\section{The New Century Handbook of English}

Literature. Ed. by Clarence L. Barnhart and William D. Halsey. New York, Appleton-Century-Crofts, 1956. 1,167p. \$12.

Designed to "answer those questions about English writers, works of literature, characters from works of literature, and various related (but not necessarily English) items which are most likely to be raised by modern American readers of English literature." The scope of the work is extended to include outstanding Irish writers and the more important "Anglo-Americans." It offers a preponderance of names, real and fictional, but includes definitions of terms, brief plot sum- 
maries, and some general critical comment. There are numerous cross-references and pronunciation is indicated. Its defined limits place this new compilation somewhere between the Oxford Companion to English Literature (Guide R281) and the Reader's Encyclopedia (Guide R29) though it includes some items not found in either, making it a welcome addition to the reference shelf. -E.S.

Pop, Sever. Bibliographie des questionnaires linguistiques. Publiée avec une subvention de L'Organisation des UNESCO. Louvain, Commission d'Enquète Linguistique [1955] 168p. (Comité International Permanent de Linguistes. Commission d'Enquète Linguistique. Publications. 6) 160 fr.

Of major interest to scholars and research workers in the field of linguistics, this bibliography is primarily devoted to the questionnaires employed in linguistic field work, although monographs concerned with related methods of research, as well as those of historical interest, are also included. Arranged chronologically, the entries cover the years 1394 through 1954, and annotations and sources of reference, usually the author's $L e$ dialectologie (Louvain, 1950), are given for each item. The work is intended to provide the basis for an eventual history of the subject. There are indexes of personal names, geographical names and subjects.-K.L.

Pyritz, Hans. Goethe-Bibliographie. Heidelberg, Carl Winter, 1955- . Lfg. 1- . \$1.95 per lfg.

This highly selective bibliography, to be complete in 8 to 10 fascicles, will list only scholarly publications needed for Goethe research. Covering Goethe literature to the end of 1954 on a systematically critical and selective basis, it will serve as a guide for scholars and librarians to the vast field of Goethe criticism of which a comprehensive inventory can be found in Goedeke's Grundriss (Guide R505). Arrangement is by types of publications, i.e., editions of Goethe's works, textual criticism, biography, etc., with chronological listing of items under each chapter. Bibliographical information is detailed and there are some annotations.-S.S.
Wright, Austin. Bibliographies of Studies in Victorian Literature for the Ten Years, 1945-1954. Urbana, University of Illinois Press, 1956. 310p. \$5.

Reprints of the annual Victorian Bibliographies, 1945-1954, published in Modern Philology. Forms a sequel to W. D. Templeman's Bibliographies of Studies in Victorian Literature . . 1932-1944 (Guide R277).

\section{GEOGRAPHY}

[Atlas mira] English Translation to Atlas Mira [by] Vladimir G. Telberg. Translation and key to: Glavnoe upravlenie geodezii $i$ kartografii USSR. Atlas of the World/Atlas Mira. Chief ed., A. N. Baranov. Moscow, 1954. New York, Telberg Book Co., 1956. 87p. $\$ 25$.

Mr. Telberg has provided, in mimeographed form, a translation of the text and legends of the important Russian world atlas. Introductory material of the separate index gazetteer is also included. The translator has added an abbreviated index and an appendix section with "the intention ... to issue from time to time the appendices which would contribute towards the revision of the Atlas Mira," e.g. population figures. The Library of Congress transliteration system is used. The work would have benefited by more stringent English editing and proofreading, but the unusual layout is essentially clear. -E.B.

Gt. Brit. General Register Office. Census 1951. England and Wales. Index of Place Names. London, Stat. Off., 1955. 2v. $£ 33 \mathrm{~s}$.

"An index of place names was first produced in the series of Census publications in 1831 , and most recently in 1924 as a separate volume in the 1921 series of Census publications." This edition gives names of every area mentioned in the tables of the various census volumes, and also villages, hamlets and localities without legally defined barriers, indicating location and 1951 population.

Kosack, Hans Peter and Meine, Karl Heinz. Die Kartographie 1943-1954, eine bibliographische Ubersicht. Lahr/ 
Schwarzwald, Astia Verlag, 1955. 216p. DM26.

Owing to the tremendous advances in map-making made during World War II, this bibliography of books, periodical articles and serial publications of societies and governments on all phases of cartography will be particularly valuable. Material in all languages is included, although there is a preponderance of German titles. The classed arrangement includes the following subjects: the history of cartography, allied fields (geography, photogrammetry and topography), official and private map-making, subject maps, map materials used in schools, photographic techniques, and instruments measures. There is an index of authors. -K.L.

\section{BIOGRAPHY}

American Men of Science: a Biographical Directory, ed. by Jaques Cattell. 9th ed. v.3, The Social and Behavorial Sciences. N.Y., Bowker, 1956. 762p. \$20.

For v.1, Physical Sciences and v.2, Biological Sciences, see Supplement 2N27. Volume 3 includes the sketches of persons in psychology, geography and anthropology previously included in American Men of Science and new sketches in other fields of the social sciences. It was first planned to include historians so that biographies were requested for this purpose but it was later decided to hold these for publication in the third edition of the Directory of American Scholars, scheduled for 1957, which will include all those in the humanities fields, including history. Many cross references to this projected volume are given.

Kaufman, I. M. Russkie biograficheskie i biobibliograficheskie slovari. [Rev. and enl. ed.] Moskva, Gosudarstvennoe izdatel'stvo kul'turnoprosvetitel' noi literatury, 1955. 751 p. 31r.40k.

Kaufman's valuable work is a guide to Russian biography and biobibliography in a wide range of fields, from the eighteenth century through 1954. The 1950 edition (Supplement 1S27) contained 735 entries; the new edition has 1592, most of which are annotated in detail. The focus is Russian "science and culture," and some individuals of primarily political importance are omitted. The name index is comprehensive, completely indexing most of the sources listed. Title and series indexes provide further access to the classified arrangement. In research libraries where the bibliography of Russian contributions is utilized, the work serves as a supplement to such tools as Arnim and Poggendorff.-E.B.

\section{Kürschners biographisches Theater-} Handbuch; Schauspiel, Oper, Film, Rundfunk. Deutschland, Österreich, Schweiz, hrsg. von Herbert A. Frenzel und Hans Joachim Moser. Berlin, Walter de Gruyter, 1956. 840p. \$14.50.

Offers information on the lives and careers of German, Austrian and Swiss personalities in the fields of theatre, opera, film and radio, including writers, directors, etc., as well as performing artists. For the latter, particular attention is given to debuts, engagements, roles played, and film appearances. In some cases references are made to biographies in Kürschners Deutshcer Gelehrten-, Literatur-, and Musiker-Kalenders for further information. A number of persons who gained fame in Germany but now live abroad are included.-E.S.

Who's Who in Germany. Munich, International Book and Publishing Co., 1956. 1,311, 114p. \$20.

Published in English under the auspices of the Central European Times Publishing Company, this new directory contains about 10,000 biographies of prominent persons of the German Federal Republic, plus a listing of some 2,300 organizations, associations and institutions. The usual biographical material is included, based, whenever possible, on information furnished by the biographee, and with no attempt to relate length of the sketch to importance of the personality. The separately paged "Directory of Organizations" is mainly a classified list with addresses, though a statement of purpose or other descriptive remark is sometimes included.-E.S.

Who's Who: Israel, 1955- . Ed. by Pereta Dagan and Amiel Sharaga. Tel Aviv, P. Mamut, P.O.B. 2001, [1955]- 
Added t.p. in Hebrew.

For earlier editions see Supplement 2 S20.

This edition for the first time gives the biographical sketch in Hebrew with an English summary.

\section{HISTORY}

Bibliographie internationale des travaux historiques publiés dans les volumes de "Mélanges," 1880-1939. Établie avec le concours des comités nationaux sous la direction de Hans Nabholz par Margarethe Rothbarth et U. Helfenstein. Ed. par le Comité International des Sciences Historiques. Paris, Armand Colin, 1955. 443p. 3,500 fr.

The valuable essays appearing in Festschriften or homage volumes have been largely lost because of inadequate indexing, but, fortunately, there have been several bibliographies of late in various subject fields indicating the contents of such volumes. A welcome addition to these is this comprehensive international bibliography of historical articles, which in the first part lists under country of origin, the volumes indexed, from twenty-five European countries. In the second part, articles contained in the volumes listed in part one, are arranged by class followed by a list of subjects treated. There is an index of the persons, historical events, and scientific institutes and societies to which the volumes of "Mélanges" are dedicated, and an index of authors.

Clark, Thomas Dionysius. Travels in the Old South, a bibliography. Norman, University of Oklahoma press, 1956. 2 v. illus., facsms. $\$ 20$.

Five hundred and seventy items, covering the years 1527 through 1825, are included in the two volumes, arranged in seven sections according to period and region. Each section has been compiled by a specialist, who has contributed a brief preface as well as assumed responsibility for choice and bibliographic description of the individual items. Although there is considerable variation in form of bibliographic entry, description is generally detailed, and there are full annotations indicating the value of each item for historical research. Each volume has a single index of authors, subjects, and of persons and places mentioned in titles and annotations.J.N.W.

Fairbank, John King and Banno, Masataka. Japanese Studies of Modern China; a Bibliographical Guide to Historical and Social-Science Research on the 19th and 20th Centuries. Rutland, Vt., Published for the Harvard-Yenching Institute by C. E. Tuttle, 1955. 331p. $\$ 6$.

This companion volume to Fairbank and Liu's Bibliography of Modern China (Guide V192) describes over one thousand books and articles. Beyond its valuable bibliographic function for librarian and Far Eastern specialist the work may well interest many social scientists. Chapters are devoted to general works (textbooks and surveys), late Ch'ing political history to 1900 , political institutions, power politics (Japanese and Russian expansion), Republican China, intellectual and cultural history, economic history and institutions, Chinese society, and reference works. The general index contains additional subject headings in English and all authors, editors, compilers and titles of books and articles in Romaji. There is also a character in dex of author's names.-E.B.

\section{Gomez Molleda, D. Bibliografía histórica española, 1950-1954. Madrid, C.S.I.C., Instituto Jerónimo Zurita de Historia [e] Instituto Nicolás Antonio de Bib- liografía, 1956. 491p. 120 ptas.}

A classified list of some 6,000 titles, this work supplements the recently inaugurated Indice histórico español ( $C$ \& $R L$, July, 1956, p.341). The principal difference in the two sets, other than the period covered, is that while the Indice includes writings on Hispanic history by authors of various nationalities, the Bibliografia is restricted to historical works of Spanish authorship, including a small number of Spanish Americans. Material listed is mostly on Spain, with brief sections on other countries. There are no annotations, and the index includes only authors and titles of anonymous works.J.N.W.

Italy. Esercito. Corpo de Stato Maggiore. Ufficio Storico. Saggio bibliografico 
sulla seconda guerra mondiale. Rome [Tipografia Regionale] 1955. 524p. L. 1200.

First published in 1949, this new and enlarged edition lists nearly 2,500 works dealing with World War II. Most of the items are Italian monographs, but also included is a fair number of French, English and German titles. Some government documents and clandestine publications are also listed. Arrangement is alphabetical by author with detailed bibliographical information and a descriptive annotation for each item. There is a classified index.-S.S.

Peel, Bruce Braden. A bibliography of the Prairie Provinces to 1953. [Toronto,] University of Toronto press, [1956]. 680p. \$10.

A selective bibliography of books and pamphlets, this work is primarily directed towards the discovery and development of the prairie region of Canada, which area the compiler defines as "that agricultural arc resting on the international boundary." Included are accounts of early explorers and travelers, pamphlets concerning the building of the Canadian Pacific Railway, British blue books and Canadian Sessional Papers, fiction and poetry with a prairie locale, and the writings published in languages other than English of the racial groups who have settled there. Unfortunately, local imprints, provincial government documents and technical bulletins relating to agriculture have not been listed. Most of the items were examined by the compiler, consequently, bibliographical information is detailed and location of copies is indicated. Since the work is arranged chronologically, there are indexes of subjects and authors, the latter with brief biographical notes.-K.L.

Rössler, Hellmut and Franz, Günther. Sachwörterbuch zur deutschen Geschichte. München, Oldenbourg, 1956-
. Lfg. 1-2. (In progress) Subscription price, per lfg.

Planned as a companion volume to the authors' Biographisches Wörterbuch zur deutschen Geschichte (Supplement 1V49) this new compendium of German history, in dictionary form, deals with "events, institutions, countries, peoples, and ideas," including the cultural, economic and political aspects. The initials of Professors Franz, Hoppe or Rössler appear at the end of most articles; others are signed by specialists in law, art, music, etc. Numerous cross references tie the material in with the biographical volume, which also uses symbols referring to the dictionary. Clear printing and good paper help to compensate for the maze of abbreviations unfortunately typical of many German handbooks. The work is to be completed in seven fascicles appearing at about two-month intervals.-E.B.

Turnbull, Robert J. Bibliography of South Carolina, 1563-1950. Charlottesville, University of Virginia press [for the Bibliographical Society of the University of Virginia] 1956. 5v. \$85.

A chronologically arranged list of manuscripts and printed books by South Carolinians or pertaining to the state from 1563 to 1950 , "the work is produced here as an uncorrected typist's copy posthumously made from an author's uncompleted handwritten manuscript" (prefatory note). Indeed, the original appears so "uncompleted" and the copy so "uncorrected" that the wisdom of publication in this form seems questionable, particularly so at the price. Although a wealth of bibliographic information is included, the inconsistencies of entry and the amateur technique employed throughout will probably limit the value of the work to a highly specialized circle. An index mentioned in the Society's brief preface, which was not included in the set received in the reviewer's library, would, of course, make the work considerably more useful.-J.N.W. 